\title{
Tulane
}

\author{
Tulane Economics Working Paper Series
}

\section{Identifying Demand Responses to Illegal Drug Supply Interdictions}

\author{
Scott Cunningham \\ Department of Economics \\ Baylor University \\ Waco, TX \\ scott_cunningham@baylor.edu
}

\author{
Keith Finlay \\ Department of Economics \\ Tulane University \\ New Orleans, LA \\ kfinlay@tulane.edu
}

Working Paper 1312

March 2013

\begin{abstract}
The optimality of supply interventions for addictive drugs is a function of demand responses to price, enforcement costs, and the relative size of external costs. Researchers need credible estimates of demand responses, but most research designs use price series affected by law enforcement actions. We present plausibly causal estimates of the price elasticities of demand for various drugs when enforcement costs are relatively low. We exploit arguably exogenous shocks to methamphetamine supplies to identify the effect of methamphetamine prices on demand for methamphetamine, alcohol, cocaine, heroin, and marijuana. Methamphetamine demand is price inelastic with substantial substitution to other drugs.
\end{abstract}

Keywords: illegal drugs, addiction, demand, substitution, War on Drugs, methamphetamine JEL: I12, I18, K42 


\title{
Identifying Demand Responses to Illegal Drug Supply Interdictions
}

\author{
Scott Cunningham and Keith Finlay*
}

February 23, 2013

\begin{abstract}
The optimality of supply interventions for addictive drugs is a function of demand responses to price, enforcement costs, and the relative size of external costs. Researchers need credible estimates of demand responses, but most research designs use price series affected by law enforcement actions. We present plausibly causal estimates of the price elasticities of demand for various drugs when enforcement costs are relatively low. We exploit arguably exogenous shocks to methamphetamine supplies to identify the effect of methamphetamine prices on demand for methamphetamine, alcohol, cocaine, heroin, and marijuana. Methamphetamine demand is price inelastic with substantial substitution to other drugs.
\end{abstract}

Keywords: illegal drugs, addiction, demand, substitution, War on Drugs, methamphetamine JEL codes: I12, I18, K42

*Department of Economics, Baylor University, Waco, TX, 254-710-4753, scott_cunninghamebaylor.edu; and Department of Economics, 206 Tilton Hall, Tulane University, New Orleans, LA 70118, 504-862-8345, kfinlay@tulane.edu. Finlay is the corresponding author. We thank the National Science Foundation (award SMA-1004569), Robert Wood Johnson Foundation (award 70509), and Tulane Research Enhancement Fund for support. Both authors have contributed to the data collection, analysis, and writing of this manuscript. Neither author has a financial interest or conflict of interest related to the findings reported in this paper. Data and codes can be obtained from the corresponding author. 


\section{Introduction}

Costs related to the prohibition of addictive drugs and the enforcement of drug laws are as much as $\$ 40$ billion annually in the US (Miron and Waldock, 2010). The US incarceration rate per 100,000 residents grew from 100 in 1980 to 492 in 2011, while the share of prisoners convicted of drug offenses increased from $22 \%$ to $48 \%$ during the same period (Blumstein and Beck, 1999; Carson and Sabol, 2012). The efficacy of enforcement-oriented interventions is uncertain given evidence of diminishing returns to imprisonment in reducing crime including drug use and trafficking (Johnson and Raphael, 2012). To evaluate the optimality of alternative policies for addressing the public health costs of addictive drugs, researchers need credible estimates of the demand responses to those policies. Enforcement strategies continue under the assumption that those efforts increase prices sufficiently to reduce demand. In this paper, we present plausibly causal estimates of the price elasticities of demand for various drugs in a setting in which enforcement costs are relatively low.

The large economic costs of substance abuse include the impact of addiction on quality of life, the crowd out of public resources, the relationship of drugs to crime, and the impacts on the families of users. ${ }^{1}$ Methamphetamine, the focus of this study, now ranks second behind marijuana as the most widely used illegal drug with damages that originate from its production and use. Public health costs such as child maltreatment, foster care admissions, environmental damage, and hospitalization greatly contribute to methamphetamine's high social cost—estimated at $\$ 23.4$ billion in 2005 (Nicosia et al., 2009).

Methamphetamine is relevant for evaluating drug policy because its economic costs are large and its production process may allow cost-effective supply interdictions. Unlike many other illegal drugs, methamphetamine (meth) is synthesized from chemical precursors produced in concentrated global input markets. Restricting precursor supplies can decrease quantity and increase price without increasing imprisonment. Compared to public awareness campaigns targeted at meth demand (Anderson, 2010), precursor controls have been temporarily successful at reducing demand (Dobkin and Nicosia, 2009; Cunningham and Finlay, 2013). Precursor controls may have only temporal effectiveness because of large potential profits in underground meth markets and

\footnotetext{
${ }^{1}$ See Cook and Moore (2000); Chaloupka and Warner (2000); and Cawley and Ruhm (2011) for a review of the social costs of substance abuse and risky behaviors.
} 
incomplete regulation of precursor supply chains.

It is surprising how few credible estimates of demand elasticities for illegal drugs exist given its importance in the design of optimal drug policy (Becker et al., 2006). The simultaneity of supply and demand for each drug confounds estimates of demand elasticities as causal measure of demand response to price changes. For example, suppose that the government chooses a prohibition and enforcement policy for reducing illegal drug consumption, then increases the number of police tasked with arrested drug traffickers and users. This strategy, potentially unobservable to the researcher, will both increase production costs for providers and increase the risk of punishment for users.

Our research design overcomes these confounds through an instrumental variables strategy that exploits two large, exogenous meth price shocks caused by two federal interdictions that created temporary shortages of the key chemical precursors used in meth production. To estimate own- and cross-price elasticities of demand for drugs, we collect monthly data on substance abuse treatment admissions as a proxy for the number of substance users, retail drug prices, and a variety of other potentially relevant factors for US states from January 1995 to December 1999 and estimate instrumental variables models of the effect of meth prices on treatment admissions for various substances. With this instrumental variable strategy, we show that the demand curve for meth is downward-sloping but inelastic and that alcohol, heroin, cocaine, and marijuana are all temporary substitutes for meth. At their peak, cross-price elasticities are about one-third the size of the ownprice effects and attenuate within six months from the start of the price shocks.

Using the own-price elasticity of -0.25 and assuming zero marginal costs of enforcement, we show that precursor control is socially optimal if the negative social externality from meth is more than four times its private value to users. Meth may have relatively large social costs. But if marginal costs of enforcement are positive and precursor controls are only temporarily effective, then precursor controls are less likely to be cost effective (e.g., precursor control burdens legitimate medical consumers). The next section provides background of drug demand and meth interventions. We then describe the empirical model and the data, discuss our results, and conclude. 


\section{Background}

\section{Optimal drug enforcement}

In a normative economic approach to drug policy, a government would choose policies that minimize the social costs of drug use. Becker et al. (2006) contrast the social welfare under a free market for drugs with a regime where drug quantities are reduced through enforcement and punishment. They show that the optimal level of enforcement depends on whether demand is inelastic, the size of the negative externalities from drug consumption and the costs of enforcement. If the social planner wishes to choose a level of enforcement, $E$, that maximizes the net benefits of consumption minus the sum of production and enforcement costs, then the following first-order condition must hold in equilibrium:

$$
C_{1}+C_{2}\left(Q+E \frac{d Q}{d E}\right)+C_{3}\left(\theta \frac{d Q}{d E}+Q \frac{d \theta}{d E}\right)=V_{q} \frac{d Q}{d E}-M R \frac{d Q}{d E},
$$

where $Q$ is the quantity of drugs consumed, $\theta$ is the odds ratio expression of the probability of arrest, $V_{q}$ is the marginal social willingness-to-pay for illegal drug consumption, and $M R$ is the marginal revenue for drug suppliers. The marginal cost of enforcement contains both a public good component, $C_{1}$, that is invariant to the quantity of drugs, and a private component, $C_{2}$, that varies with quantity. The final component of the marginal cost of enforcement is $C_{3}$, which measures the costs of punishing arrested users. The right-hand side of equation 1 measures the marginal benefit of reduced consumption.

If we assume that marginal costs of enforcement are zero, we can rearrange Equation 1 so that the role of price elasticity of demand in optimal drug policy is more transparent:

$$
\frac{V_{q}}{P}=1+\frac{1}{\epsilon_{d}}
$$

where $\epsilon_{d}$ is the price elasticity of demand for drugs and $P$ is the price paid by consumers for drugs. As price equals the private willingness to pay in competitive markets, the left-hand side of Equation 2 equals the ratio of marginal social to private value of illegal drug consumption. If demand is inelastic, then both the right-hand side and left-hand side of Equation 2 must be 
negative in order for non-zero levels of drug enforcement to be optimal. This requires negative externalities in consumption, $V_{q}<0$, given that price is non-negative.

If demand is inelastic and the negative externalities in consumption are relatively small, then the free market level of consumption is socially optimal. This is because production and distribution costs are rising as output falls at a loss in social utility from reduced consumption. If meth demand is inelastic, then government intervention is justified if and only if the social value of meth consumption is "very negative". Thus even in a world where the marginal costs of enforcement are essentially zero, inelastic demand implies that enforcement is optimal only when there are substantial negative externalities from consumption, and even then, quantity restrictions will absorb a considerable amount of resources.

If we relax the zero marginal cost assumption, we find marginal enforcement costs are rising as demand becomes less elastic. This is because consumption falls more slowly when demand is inelastic, and since expenditures on apprehension and punishment depend on output, a slower fall in output with inelastic demand will cause enforcement expenditures to grow more rapidly. Therefore we can conclude that falling consumption causes total production costs and enforcement costs to rise more rapidly when demand is inelastic.

There is some pessimism about the efficacy of supply-side interventions among researchers. An early study by Rydell and Everingham (1994) suggested that supply-side strategies may not be cost effective. Prohibition and enforcement have even been shown to reduce prices contrary to economic intuition (DiNardo, 1993; Yuan and Caulkins, 1998), but this result may be explained by nonpecuinary aspects of market operation such as violence that impose externalities on suppliers (Caulkins et al., 2006). Given the high social costs of incarceration, this evidence is consistent with evidence that enforcement strategies may not be cost effective (Kuziemko and Levitt, 2004).

These studies rarely use research designs capable of identifying the causal effects of enforcement. One exception is DeSimone (2001) who estimates the causal effect of cocaine prices on crime using instrumental variables. He instruments for price with measures of wholesale supply factors and retail enforcement intensity. But if enforcement determines crime directly, these instruments are possibly not excludable from the second-stage equations. Nicosia et al. (2009) estimate the causal effect of meth on crime using the 1995 ephedrine interdiction for California and find no effect. Cunningham and Finlay (2013) use state-level data and both the 1995 and 1997 precursor 
interventions and identify a positive elasticity foster care admission with respect to meth use.

\section{Estimated price elasticities of drug demand}

The own- and cross-price elasticities of short and long-run demand enable policymakers to forecast the impact of and evaluate the cost effectiveness of a given intervention. It would also provide some guidance as to when demand-side interventions may be the more cost effective approach. Most economic studies suggest that addictive substances are consumed on the inelastic portion of demand. For example, Chaloupka and Warner (2000) and Gallet and List (2003) agree that most studies estimate the own-price elasticities for tobacco to be -0.3 to -0.5 . Similarly, Cook and Moore (2000) notes that the average own-price elasticity for beer, wine and spirits is -0.35 , -0.68 , and -0.98 , respectively, which is also found in more updated reviews such as Wagenaar et al. (2009). Gallet (2007) finds a median elasticity for alcohol of -0.55 across 132 studies.

In comparison, our knowledge about cross-price elasticities for addictive substances is much less developed. Few economists have attempted to calculate cross-price elasticities for tobacco, and those which do exist typically only focused on the within-tobacco categories and various intensive margins, such as higher tar cigarettes and smokeless tobacco products. Ohsfeldt and Boyle (1999) estimates the cross-tax elasticity of snuff use with respect to cigarette prices at 0.98 for males older than 16, whereas Decker and Schwartz (2000) estimated a negative cross-price elasticity for cigarettes and alcohol reflecting complementarities in consumption.

Knowledge of the elasticities of demand for illicit substances is less mature than our knowledge of the same for alcohol and tobacco due both to the smaller number of economic studies on illicit substances and the unique challenges associated with studying illicit drugs. There is considerable variation in the magnitude of elasticities of demand for heroin and cocaine. For example, Dave (2008) estimates own-price elasticities of cocaine and heroin at -0.27 and -0.10 , respectively, using emergency department visits, but Caulkins (2001) estimates an own-price elasticity of demand for cocaine and heroin at -1.3 and -0.84 , respectively, using hospitalizations. Saffer and Chaloupka (1999) estimated -0.82 to -1.03 for heroin prevalence elasticities of demand, and -0.28 to -0.44 for cocaine. Liu et al. (1999) find evidence that opium is inelastic in the short-run (-0.48), but elastic in the long-run (-1.4), whereas Ours (1995) estimates an elasticity 
of -0.7 and -1.0 in the short and long-run, respectively. Differences in the magnitudes are due to a combination of data aggregation, identification strategy, the time dimension and the choice of the proxy. Cross-price elasticities of demand for drugs have rarely been attempted, and to our knowledge, no one has found strong statistical evidence that they exist. Saffer and Chaloupka (1999) and Dave (2006) both attempted to estimate cross-price elasticities, but neither found statistically significant results. To our knowledge, there have been no studies of drug demand responses to meth prices.

\section{Methamphetamine and precursor control}

A recent study by the Rand Corporation calculates that the total economic costs of meth production and use were $\$ 23.4$ billion in 2005. While the majority of this calculation can be attributed to reduced quality of user lives, a large share of total costs were externalities to nonusers caused by reduced worker productivity, harm to children, crime, and pollution (Nicosia et al., 2009). Only a few studies have attempt to estimate the causal effect of meth use on public health outcomes. Dobkin and Nicosia (2009) find no evidence that meth causes crime, whereas Cunningham and Finlay (2013) estimate a positive elasticity of foster care admissions with respect to meth use due to increased child neglect and abuse. Meth dependency affects user brain chemistry with evidence of long-term increases in psychosis, paranoia, and aggression (Rawson et al., 2001).

Meth is synthesized from a reduction of ephedrine or pseudoephedrine, the active ingredients in commonly used cold medicines, so meth production requires access to legitimate input markets. While cold medications can be purchased at retail pharmacies, large quantities of bulk precursors can only be obtained in wholesale markets that are subject to chemical trafficking regulations. These chemicals are not produced domestically. Suo (2004) reports that in 2004, only nine international factories manufactured the bulk of the world supply of ephedrine and pseudoephedrine.

Since these precursors are distributed and packaged in different forms, the history of precursor control is one in which meth producers innovate around narrow restrictions on precursors created by federal legislation. In 1988, Congress passed the Chemical Diversion and Trafficking Act that gave the DEA the authority to control the wholesale distribution of precursors used to produce illegal drugs, such as meth, LSD, and PCP. The statute required bulk distributors of ephedrine and 
pseudoephedrine to notify drug enforcement authorities of imports and exports and keep records of purchasers (Suo, 2004; [US DEA] United States Drug Enforcement Administration, 1997). All tablet forms of ephedrine and pseudoephedrine medical products, however, were exempt-a legal loophole that drug trafficking organizations quickly exploited.

The primary sources of precursors following the 1988 regulation were wholesale and mail order distributors of ephedrine tablets. In the early 1990s, there was little use of pseudoephedrine as a precursor. In 1994, ephedrine was identified as the source material in 79\% of meth lab seizures, while pseudoephedrine was only found in $2 \%$ (Suo, 2004). Congress sought to close the legal loophole in 1993 by passing the Domestic Chemical Diversion Control Act, which became effective August 1995. This new regulation provided additional safeguards by regulating the distribution of products that contained ephedrine as the only active medicinal ingredient ([US DEA] United States Drug Enforcement Administration, 1995; Cunningham and Liu, 2003). The new legislation ignored pseudoephedrine tablets, so traffickers soon took advantage of the omission by substituting towards pseudoephedrine as a precursor. By 1996, pseudoephedrine was found to be the primary precursor in almost half of meth lab seizures ([US DEA] United States Drug Enforcement Administration, 1997). From 1996 to 1997, pseudoephedrine imports grew by 27\% while sales of all cold medications grew only $4 \%$ (Suo, 2004). As a consequence, the DEA sought greater controls over pseudoephedrine products. The Comprehensive Methamphetamine Control Act of 1996 went into effect between October and December 1997 and required distributors of almost all forms of pseudoephedrine to be subject to chemical registration ([US DEA] United States Drug Enforcement Administration, 1997).

In the short-run, these precursor controls may have been the most successful supply-side interdictions in the history of US drug enforcement (Dobkin and Nicosia, 2009). ${ }^{2}$ Evidence of this can be seen in its effect on meth prices. We construct a monthly price series for a pure gram of meth, heroin and cocaine using the DEA's System to Retrieve Information from Drug Evidence (STRIDE) database. ${ }^{3,4}$ Our monthly price series is from January 1995 to December 1999. We use

\footnotetext{
${ }^{2}$ The long-run effects of these wholesale regulations were more muted, as meth producers appear to have adapted to the increased restrictiveness of domestic precursor acquisition by relocating operations out of the US, shifting to new technologies, and substituting from wholesale to retail purchases (e.g., pharmaceutical purchases of cold medications with active pseudoephedrine).

${ }^{3}$ See Appendix A for a more detailed explanation of the construction of the drug price series used in the paper.

${ }^{4}$ There is a debate about the ability of researchers to recover the distribution of market prices from STRIDE because its sampling is determined by law enforcement actions. See Horowitz (2001) for the critical argument and Arkes et al.
} 
an empirical method to identify the windows during which each intervention was effective by first regressing real expected meth prices onto a cubic time trend. We then add a single-month fixed effect for each month after the intervention began-retaining only those that are statistically significant. We repeat these steps until the last contiguous, post-intervention month dummy variable is statistically insignificant. The Domestic Chemical Diversion Control Act became effective in August 1995, and our method identifies deviations in price trends from September 1995 until February 1996. The Comprehensive Methamphetamine Control Act became effective between October and December 1997, and our model identifies detectable deviations in price trends from April 1998 to March 1999. 5

Figure 1 shows the median monthly expected price of meth, heroin, and cocaine relative to their respective median values in January 1995. We mark the window of the two federal interdictions' efficacy with vertical bars. The 1995 shock caused meth prices to more than quadruple in a brief period of time. Prices returned to pre-interdiction levels after six months. The 1997 interdiction was comparatively smaller in magnitude, but caused meth prices to increase over their pre-interdiction levels for twelve months. These large but temporary disruptions in meth markets are key to our identification of the demand elasticities. For comparison, we present expected price of cocaine and heroin (relative to their January 1995 median values) on the same graph. There is no similar change in median heroin or cocaine prices relative to pre-interdiction levels during either intervention suggesting that the effect is the result of unique factors in meth markets. ${ }^{6}$

\section{Estimation, identification, and data}

We are interested in the causal effect expressed as an elasticity measure of meth prices on the demand for meth $(m)$, alcohol $(a)$, marijuana $(m j)$, cocaine $(c)$, and heroin $(h)$ (with drugs indexed (2008) for a rebuttal.

${ }^{5}$ Our empirical method for dating the interventions in this paper is similar to previous studies. Dobkin and Nicosia (2009) use a four-month window for the 1995 intervention, but they limit their attention to California where the meth market is the most sophisticated and producers are arguably more adaptable. Cunningham and Liu (2003, 2005) use six months for the 1995 intervention (August 1995-January 1996).

${ }^{6}$ Since 2000, there have been a variety of state-level precursor controls, ranging from quantity restrictions to electronic tracking of purchases to doctor prescription requirements. Since producers can obtain inputs from neighboring states, the price effects of these interventions are smaller and evidence suggests the demand responses are also smaller (Nonnemaker et al., 2011; [US GAO] United States Government Accountability Office, 2013). 
by $i$ ). Consider linear demand equations of the form:

$$
\ln \left(Q_{s t}^{i}\right)=\beta_{\mathrm{OLS}}^{i} \ln \left(P_{s t}^{m}\right)+\gamma^{i} X_{s t}+\varepsilon_{s t}^{i} \quad \forall i \in\{m, a, m j, c, h\},
$$

where $Q$ is self-referred treatment admissions, $P^{m}$ is the retail price of a pure gram of meth $(m)$, and $\varepsilon$ is the error term. The vector $X$ includes state fixed effects, month-of-year effects, a national time trend, other state-level drug prices if they are available, the state population aged 15-49 years, and the state unemployment rate. The unit of observation is state $s$ in month $t$, and all regressions are weighted by the population aged 15-49 years. The parameters of interest are $\beta^{m}$, the ownprice elasticity of demand for meth, and the $\beta^{i \neq m} \mathrm{~s}$, the cross-price elasticities of demand for the other drugs.

Price and quantity in Equation 3 are observed in market equilibrium. The simultaneity of supply and demand for each drug confounds the interpretation of $\beta_{\text {OLS }}^{i}$ as a causal measure of the demand response to price changes. For example, suppose that the government chooses a prohibition and enforcement policy for reducing illegal drug consumption, then increases the number of police tasked with arrested drug traffickers and users. This strategy, potentially unobservable to the researcher, will both increase production costs for providers and increase the risk of punishment for users. The equilibrium prices and quantities reflect both of these responses, so $\beta_{\text {OLS }}^{i}$ may be biased by the omission of unobserved law enforcement variables.

In order to identify the demand response to drug price changes, we use an instrumental variables strategy and estimate a two-stage least squares (2SLS) model. Our instrumental variable is an indicator variable equal to one for months when the 1995 and 1997 federal interventions had significant disruptions on meth markets and zero for all other months (as described above). The first-stage meth price model is:

$$
\ln \left(P_{s t}^{m}\right)=\zeta Z_{t}+\pi X_{s t}+\omega_{s t}
$$

where $\omega_{s t}$ measures the unobserved determinants of meth prices in state $s$ and month $t$. The second-stage demand model becomes:

$$
\ln \left(Q_{s t}^{i}\right)=\beta_{\mathrm{IV}}^{i} \ln \left(\widehat{P_{s t}^{m}}\right)+\tilde{\gamma}^{i} X_{s t}+\tilde{\varepsilon}_{s t}^{i} \quad \forall i \in\{m, a, m j, c, h\}
$$


where $\ln \left(\widehat{P_{s t}^{m}}\right)$ is the fitted log meth price from our first stage model. To identify $\beta_{\mathrm{IV}}^{i}$, the instrument $Z_{t}$ must be correlated with meth prices, which we establish in Figure 1. Identification also requires that the instrument only affect drug demand through its affect on meth prices. Although we know of no contemporaneous increases in law enforcement effort during the intervention periods, we focus on self-admitted treatment admissions to isolate the demand response that is most likely to be independent of police effort. ${ }^{7}$

Our measure of demand is a proxy and deserves a discussion. Proxies are often used in illegaldrug research because of the inherent difficulty in observing underground markets and because of underreporting of illegal behavior in surveys of individual behavior. We also need monthly data to properly time the meth precursor interventions and admissions to drug treatment facilities are a frequent event that can be aggregated to the state-month level. Admissions are likely to be correlated with drug use, but must also satisfy other characteristics for us to consider $\beta_{\mathrm{IV}}^{i}$ an elasticity of drug (use) demand. Suppose that a constant proportion, $0<\zeta<1$, of total meth users are in treatment at any given time with an multiplicative iid measurement error $\eta \sim \ln \mathrm{N}\left(0, \sigma_{\eta}^{2}\right)$. As long as $\zeta$ and $\eta$ are not systematically different during the precursor interventions, $\zeta$ will be absorbed by the constant term and $\eta$ will be absorbed by the error term, and we can still identify the elasticities of interest.

To estimate Equations 3-5, we combine state-month data from a variety of sources. We choose a sample period of January 1995 to December 1999 for all datasets. This starts eight months before the first intervention and ends nine months after the second intervention. We construct an estimated price series for a pure gram of meth, heroin and cocaine/crack using the DEA's System for the Retrieval of Drug Evidence (STRIDE) dataset. ${ }^{8}$ All prices are adjusted to 2002 dollars using the All Urban CPI series. Drug price observations do not occur in every state-month cell. To impute price observations for missing cells, we take price averages from higher level geographic areas, moving from states, to census divisions, to census regions, and finally to national price series. This imputation should reflect the price users must pay in a particular state. We show a comparison of both sets of price series in Table 1. The two sets have similar means but the series

\footnotetext{
${ }^{7}$ The local average treatment effect interpretation of the IV parameter is a consideration if price responses to interventions are systematically different in intervention periods. We have no reason to believe heterogeneity in demand responses to price exists, but the first-stage monotonicity requirement is likely to be satisfied in any case.

${ }^{8}$ Most marijuana observations in STRIDE are due to seizures. As a result, they are missing price data. Marijuana purity also is not available, making it impossible to generate a reliable price or purity series using these data.
} 
with imputed prices have smaller variances.

Drug treatment admissions data comes from the Department of Substance Abuse and Mental Health Administration's Treatment Episode Data Set (TEDS). TEDS records the universe of all federally funded treatment inpatient or outpatient facilities. Patients admitted are interviewed to determine the routes of admission, as well as which substances were used at their most recent treatment episode. We use the number of treatment admissions by substance abuse category as proxies for the following substances: meth, alcohol, cocaine/crack, heroin and marijuana. We report both the total admissions aggregated over all routes of admissions as well as the number of self-referred admissions for each substance abuse variable of interest.

The population of those aged 15-49 years in each state in 1,000s comes from SEER (2011). Statelevel unemployment rates were obtained from the Current Population Survey. We also include state cigarette taxes measured as real dollars per cigarette pack (Orzechowski and Walker, 2011).

\section{Results}

All models use the log of the treatment admissions as dependent variables and log of meth prices as the independent variable. The regressions all have a log-log form, so the coefficients are approximately equal to elasticities. Our meth variable includes all mentions of meth, but our other substance abuse variables exclude any cases where meth was mentioned so as to avoid double counting. ${ }^{9}$ We use only self-admission cases because self-admit are those individuals who would be price responsive. ${ }^{10}$

We estimated Equation 3 using five different outcome variables: meth (Table 2), alcohol (Table 3), heroin (Table 4), crack and powder cocaine (Table 5) and marijuana (Table 6). The first two columns of each table use the same specification, and we report OLS and 2SLS estimates for comparison. Our 2SLS models are identified from the temporal shocks to meth prices created by the two precursor interdictions. As such, it would be useful to see how reduced demand for meth and substitution toward alternative drugs changes over time. In a series of figures, we plot

\footnotetext{
${ }^{9}$ TEDS admissions list their primary, secondary and tertiary substance used at the most recent episode, so it's possible for alcohol cases to occur with meth. As we do not want to bias downward estimates of cross-price elasticities by including cases where meth appeared with other drugs, we focus on cases where meth is not mentioned at all, which we view as a conservative estimate.

${ }^{10}$ Criminal justice referrals, for instance, are usually instances where a judge assigned treatment to a defendant. The theory of demand would not suggest judges are making decisions in response to price fluctuations.
} 
the coefficient estimates with different leads to illustrate the transition of the short-run elasticity to the medium-run elasticity over a six-month spell (Figures 2 and 3). These models are of the form:

$$
\ln \left(Q_{s, t+L}^{i}\right)=\beta_{\mathrm{IV}, L}^{i} \ln \left(\widehat{P_{s t}^{m}}\right)+\tilde{\gamma}_{L}^{i} X_{s t}+\tilde{\varepsilon}_{s, t+L}^{i} \quad \forall i \in\{m, a, m j, c, h\}
$$

where the demand leads run from $L=0$ to 6 .

Table 2 reveals a negative point estimate for the own-price elasticity of meth demand. The first stage results show that the real price of meth rose $63 \log$ points during the two interventions, or 87.7 percent. ${ }^{11}$ As OLS and 2SLS both agree on the sign of the elasticity, we will report the 2SLS estimates since they are better identified. While meth has inelastic demand in all seven specifications, consumer responsiveness to prices increases as we use higher order leads. The contemporaneous elasticity is -0.06 . Within two months, the elasticity has doubled, and within four months it has quadrupled. The upper bound elasticity of -0.22 to -0.25 is achieved within four months time. We present these estimates with 90\% confidence intervals in Figure 2 as well. While meth demand is becoming more elastic over time, as theory would suggest, we can only say that the elasticity reaches a max of -0.25 using the six month price leads. We do not feel comfortable exploring beyond six months given the exogenous price changes caused by the supply disruptions were temporary.

Since these are the first estimates of the own-price meth elasticity, they are not directly comparable to other estimates of the same parameter. But compared to the estimated elasticities for other drugs, our estimates suggest that meth is one of the more inelastic drugs estimated to date. The central tendency among all published elasticities for illegal drugs is negative one-half with a large standard deviation (Becker et al., 2006). Our medium-run own-price elasticity of -0.25 is most comparable to Dave (2006) who estimated a contemporaneous own-price elasticity of cocaine using annual hospitalizations as a proxy of -0.27 .

Next we discuss our estimates of various cross-price elasticities with respect to meth prices. The most common substance reported by treatment patients is alcohol by a significant margin. Using only self-referred alcohol admissions, the mean number of monthly alcohol mentions in TEDS is 613 for this period of time compared to 71 for meth (Table 1). It is perhaps in part for this ${ }^{11} e^{0.63}=1.877$ 
reason that the cross-price elasticities that we estimate are relatively small given the large volume of alcohol mentions in the data. Our evidence suggests that alcohol is a substitute for meth in the short-run, but that substitution dissipates after five months. The cross-price elasticity of demand for alcohol with respect to meth prices reaches a peak of +0.11 after two months. Assuming a baseline of 613 alcohol admissions, this implies that an $87.7 \%$ increase in prices caused by the intervention caused alcohol admissions to increase $9.65 \%$, or 59 additional alcohol admissions. The shape of the cross-price elasticity for each of the seven specifications is presented in Panel A of Figure 3.

For each alternative substance category, we find cross-price elasticities that are both positive and shaped like our alcohol estimates over time. The differences that we find typically depend on how soon the responsiveness tapers off. Heroin, for instance, reaches a similar level to that of alcohol, but begins declining sooner becoming marginally significant by the third month. The peak cross-price elasticity of demand for heroin is +0.10 , which is reached in months one and two. It declines soon thereafter becoming statistically indistinguishable from zero by the fourth month and zero in absolute value at the sixth month. We present the elasticity for heroin in Panel B of Figure 3. As can be seen when the two are side by side, alcohol appears to have been more responsive than heroin in the medium run.

The cross-price elasticity of demand for powder cocaine and crack is, like the others, positive and attenuates after its peak. Although we cannot observe past the six-month window, the trajectory suggests cocaine and meth may only be temporarily substitutable. The peak value of the cross-price elasticity of demand for cocaine is +0.12 which corresponds to the fourth month lead. This is presented in Panel C of Figure 3, as well. Finally, we present our estimates for marijuana elasticities. We find that marijuana demand grows to +0.09 by the third month after which it declines and is statistically insignificant at the sixth month. This shape is presented in Panel D of Figure 3.

Figure 3 shows that a visual representation of the information contained in the tables. All four substances have positive cross-price elasticities of demand with respect to meth prices, but only temporarily. Marijuana, heroin and cocaine become statistically insignificant or zero in the six month lead specification. Only alcohol remains positive and significant for the entire time that meth's own-price elasticity is negative and significant, but like the other drugs, alcohol's cross- 
price elasticity is on a downward trajectory at the six month lead specification.

\section{Conclusion}

To evaluate the optimality of alternative policies for addressing the public health costs of consumption of addictive drugs, researchers need credible estimates of the demand responses to those policies. Enforcement and prohibition strategies continue under the assumption that those efforts will increase prices sufficiently to reduce demand. If drug demand is price inelastic, Becker et al. (2006) show that, even if enforcement costs are zero, prohibition is only socially optimal if social externalities of drug use are much larger than private value users get from drugs. Measuring these parameters is critical for evaluating the cost effectiveness of alternative policies. In this paper, we present plausibly causal estimates of the price elasticities of demand for various drugs in a setting in which enforcement costs are relatively low (at least relative to imprisonment of users and traffickers.)

First, we provide the first consistent estimate of the own- and cross-price elasticity of demand for drugs with respect to meth prices. We show that meth demand is downward sloping and inelastic with an own-price elasticity that reaches -0.25 six months after a price shock. Our estimate is similar in magnitude to Dave (2008), but smaller in magnitude to the central tendency across all estimates (Becker et al., 2006). Secondly, our study shows that precursor controlled supply shocks are capable of shifting supply, increasing price, and reducing quantity with only marginal substitution effects to other addictive substances. This may suggest that existing meth users substituted to alternative drugs causing an increase in treatment for alternative substances, but meth initiation among new users declined with higher real prices causing substitution effects to decline even while meth treatment admissions fell.

Using an estimated own-price elasticity of demand -0.25 , precursor control is efficient if the negative social marginal willingness to pay for meth is at least four times the private benefit of meth consumption to users (Equation 2). Given recent evidence that meth increases foster care through increased child maltreatment, precursor control may meet this condition (Nicosia et al., 2009; Zill, 2011; Cunningham and Finlay, 2013). Unfortunately, both of the 1995 and 1997 precursor controls were only temporarily effective at increasing the price of meth. 
This back-of-the-envelope approach suggests that precursor control may dominate enforcement policies that rely on law enforcement to reduce drug supply given diminishing returns to prison and other costs associated with the "War on Drugs" (Johnson and Raphael, 2012). Unfortunately, the interventions studied in this paper only temporarily disrupted meth producers. It remains to be seen if interdictions are cost effective in the long run, and whether they can be implemented in a permanent way without major reductions in consumer welfare associated with reduced access to legitimate medicines. Some pharmaceutical drugs with large social costs may fit a similar regulation framework. For example, abuse of oxycodone, an semi-synthetic opioid analgesic, is the primary cause of a decade-long increase in overdose deaths in the US (Jones et al., 2013). Drugs like oxycodone require sophisticated production facilities (i.e., organic production is not possible), have the potential for large social costs from abuse, but also have some legitimate medical uses. Lessons from meth precursor regulation may help inform regulation for a broad class of legitimate medicines. 


\section{Appendix A Data appendix}

We largely follow the methodology that Arkes et al. (2004) outline to prepare a series of meth prices. This report, which the authors prepare for the White House Office of National Drug Control Policy, examines the price trends for cocaine, heroin, cannabis, and meth in the US using prices from the Drug Enforcement Agencys System to Retrieve Information from Drug Evidence (STRIDE). We acquired STRIDE through a Freedom of Information Act request. STRIDE observations come from law enforcement events such as lab seizures, undercover purchases, etc. Samples are sent to DEA labs to identify the drugs and purities. Cocaine, heroin, and meth, occur sufficiently frequently to construct a price series. On the other hand, law enforcement officers collect most cannabis observations from seizures rather than purchases, and therefore it is not possible to construct a marijuana price series.

Following Arkes et al. (2004), we keep US observations originating from undercover purchases, individual seizures, and lab seizures and drop observations with missing or nonsensical price, weight, or purity data. We link drug observations to a drug market analogous to a metropolitan statistical area. Observations outside of major metropolitan drug markets are assigned markets associated with Census divisions.

Each observation is assigned a market quantity or distribution level based on the net weight from the observation. For meth, we use three market quantities defined as having a net weight of less than ten grams, between ten and 100 grams, and more than 100 grams. For heroin, we use three market quantities with thresholds of 1 and 10 grams. For powder cocaine, we use four market quantities with thresholds of 2, 10, and 50 grams. For crack cocaine, we use three groups defined by thresholds of 1 and 15 grams. In this paper, we call meth, heroin, and cocaine observations retail if they come from the smallest two categories (i.e., less than 100 grams for meth, less than 10 grams for powder cocaine and heroin, and less than 15 grams for crack cocaine).

With the samples and market quantities defined, prices are regression adjusted to account for variation in sample purity. These regression models incorporate drug market random effects according to the following model:

$$
\text { purity }_{i j k}=\alpha_{0 k}+\alpha_{1 k} \text { time }_{i j}+\alpha_{2 k} \text { weight }_{i j k}+\varepsilon_{i j k},
$$


where time $_{i j}$ is a vector of dummy variables representing a year-month and weight ${ }_{i j k}$ is the raw weight of the $i_{\text {th }}$ observation in city $k$ at time $j$. The coefficient $\alpha_{0 k}$ represents the intercept for city $k, \alpha_{1 k}$ is a vector for the time coefficient for city $k$, and $\alpha_{2 k}$ is the amount coefficient for city $k$. The disturbance term $\varepsilon_{i j k}$ is distributed iid from normal distribution with mean zero. Our model is a random coefficients model where:

$$
\begin{aligned}
\alpha_{0 k} & =\gamma_{0}+u_{0 k}, \\
\alpha_{1 k} & =\gamma_{1}+u_{1 k}, \text { and } \\
\alpha_{2 k} & =\gamma_{2}+u_{2 k},
\end{aligned}
$$

where $\gamma_{0}, \gamma_{1}$, and $\gamma_{2}$ are, respectively, the overall mean estimates for the intercept, time, and amount effects. The random coefficients for the intercept, amount and time are each assumed to be iid across cities and distributed

$$
\left(\begin{array}{l}
u_{0 k} \\
u_{1 k} \\
u_{2 k}
\end{array}\right) \sim\left(\left[\begin{array}{l}
0 \\
0 \\
0
\end{array}\right],\left[\begin{array}{ccc}
\rho_{00} & 0 & 0 \\
0 & \rho_{11} & 0 \\
0 & 0 & \rho_{22}
\end{array}\right]\right) .
$$

Unlike Arkes et al. (2004), our specification uses month-year for time instead of quarter-year. We also constrain the off-diagonal elements of the random coefficient variance-covariance matrix at zero. This was done for computational reasons, as our models would not otherwise converge. This accounts for the within-city clustering of the intercept, time and amount, but requires that across-city correlations be zero.

After estimating the purity equation, we retain the fitted values to predict purity ( $\widehat{\text { purity), }}$ 
which is then used to estimate the following price equation:

$$
\begin{aligned}
& \mathrm{E}\left(\text { real price }{ }_{i j k} \mid \gamma_{0 k}, \gamma_{1 k}, \gamma_{2 k}\right)=\mathrm{e}^{\gamma_{0 k}+\gamma_{1 k} \text { time }_{i}+\gamma_{2 k}\left[\ln \left(\text { weight }_{i j k}\right)+\ln \left(\widehat{\text { purity }}_{i j k}\right)\right]} \text {, } \\
& \gamma_{0 k}=\beta_{0}+c_{0 k}, \\
& \gamma_{1 k}=\beta_{1}+c_{1 k}, \\
& \gamma_{2 k}=\beta_{2}+c_{2 k}, \text { and } \\
& \left(\begin{array}{c}
c_{0 k} \\
c_{1 k} \\
c_{2 k}
\end{array}\right) \sim\left(\left[\begin{array}{l}
0 \\
0 \\
0
\end{array}\right],\left[\begin{array}{ccc}
\kappa_{00} & 0 & 0 \\
0 & \kappa_{11} & 0 \\
0 & 0 & \kappa_{22}
\end{array}\right]\right) .
\end{aligned}
$$

The real price for observation $i$ in period $j$ in city $k$ is modeled as a function of time, city effects, and the sum of the natural logarithm of amount and the natural logarithm of expected purity estimated in the previous regression. The mean effects of the control variables' effect on price are captured in the estimated $\beta$ terms. The $\gamma_{0}, \gamma_{1}$, and $\gamma_{2}$ coefficients are assumed to be drawn from a normal distribution with mean zero.

We estimate the model using a linear mixed model. Except for our modeling of time as month-year and the imposed additional structure that the off-diagonal elements of the variancecovariance matrix be zero, our model is the same as that specified in Arkes et al. (2004).

To time the interventions, we use a stepwise regression procedure using the following model:

$$
\mathrm{E}\left(\text { real price }_{i j k}\right)=\delta_{0}+\tau_{t}+\tau_{t}^{2}+\nu_{i t}
$$

where expected price is a variable of individual meth price observations, $\tau_{t}$ is a linear time trend common to all states, and $\tau_{t}^{2}$ is a quadratic time trend common to all states. We start without any fixed effects for the intervention months. Stepwise, we add a single fixed effect for each month after the intervention. If the fixed effect is significant, we keep it in the model. We continue these steps until a post-intervention, contiguous-month fixed effect is no longer significant. Using this procedure, we obtain the intervention lengths. 


\section{References}

Anderson, D. Mark. 2010. Does Information Matter? The Effect of the Meth Project on Meth Use among Youths. Journal of Health Economics 29(5): 732-42.

http://www.sciencedirect.com/science/article/pii/s0167629610000779

Arkes, Jeremy, Rosalie Liccardo Pacula, Susan M. Paddock, Jonathan P. Caulkins, and Peter Reuter. 2004. Technical Report for the Price and Purity of Illicit Drugs through 2003. Santa Monica, CA: Rand Corporation.

https://www.ncjrs.gov/ondcppubs/publications/pdf/price_purity_tech_rpt.pdf

- 2008. Why the DEA Stride Data Are Still Useful for Understanding Drug Markets. NBER Working Paper 14224.

http://www. nber.org/papers/w14224

Becker, Gary S., Kevin M. Murphy, and Michael Grossman. 2006. The Market for Illegal Goods: The Case of Drugs. Journal of Political Economy 114(1): 38-60.

http://www.jstor.org/stable/10.1086/498918

Blumstein, Alfred and Allen J. Beck. 1999. Population Growth in U.S. Prisons, 1980-1996. In Michael Tonry and Joan Petersilia, editors, Crime and Justice: Prisons, volume 26. Chicago: University of Chicago Press.

http://www. amazon.com/Crime-Justice-Volume-26-Research/dp/0226808505

Carson, E. Ann and William J. Sabol. 2012. Prisoners in 2011. Bureau of Justice Statistics NCJ 239808.

http://bjs.ojp.usdoj.gov/content/pub/pdf/p11.pdf

Caulkins, Jonathan P. 2001. Drug Prices and Emergency Department Mentions for Cocaine and Heroin. American Journal of Public Health 91(9): 1446-48.

http://dx.doi.org/10.2105/AJPH.91.9.1446

Caulkins, Jonathan P., Peter Reuter, and Lowell J. Taylor. 2006. Can Supply Restrictions Lower Price? Violence, Drug Dealing and Positional Advantage. B.E. Journal of Economic Analysis and Policy 5(1): Article 3.

http://dx.doi.org/10.2202/1538-0645.1387

Cawley, John and Christopher J. Ruhm. 2011. The Economics of Risky Health Behaviors. In Mark V. Pauly, Thomas G. Mcguire, and Pedro P. Barros, editors, Handbook of Health Economics, volume 2, chapter 3, pp. 95-199. Amsterdam: Elsevier.

http://www.sciencedirect.com/science/article/pii/B9780444535924000037

Chaloupka, Frank J. and Kenneth E. Warner. 2000. The Economics of Smoking. In Anthony J. Culyer and Joseph P. Newhouse, editors, Handbook of Health Economics, volume 1B, chapter 29, pp. 1539-1627. Amsterdam: Elsevier.

http://www.sciencedirect.com/science/article/pii/s1574006400800426

Cook, Philip J. and Michael J. Moore. 2000. Alcohol. In Anthony J. Culyer and Joseph P. Newhouse, editors, Handbook of Health Economics, volume 1B, chapter 30, pp. 1629-73. Amsterdam: Elsevier. http://www.sciencedirect.com/science/article/pii/s1574006400800438 
Cunningham, James K. and Lon-Mu Liu. 2003. Impacts of Federal Ephedrine and Pseudoephedrine Regulations on Methamphetamine-Related Hospital Admissions. Addiction 98(9): 1229-37. http://dx.doi.org/10.1046/j.1360-0443.2003.00450.x

- 2005. Impacts of Federal Precursor Chemical Regulations on Methamphetamine Arrests. Addiction 100(4): 479-88.

http://dx.doi.org/10.1111/j.1360-0443.2005.01032.x

Cunningham, Scott and Keith Finlay. 2013. Parental Substance Use and Foster Care: Evidence from Two Methamphetamine Supply Shocks. Economic Inquiry 51(1): 764-82.

http://dx.doi.org/10.1111/j.1465-7295.2012.00481.x

Dave, Dhaval. 2006. The Effects of Cocaine and Heroin Price on Drug-Related Emergency Department Visits. Journal of Health Economics 25(2): 311-33.

http://www.sciencedirect.com/science/article/pii/S0167629605000809

. 2008. Illicit Drug Use Among Arrestees, Prices and Policy. Journal of Urban Economics 63(2): 694-714.

http://www.sciencedirect.com/science/article/pii/s0094119007000654

Decker, Sandra L. and Amy Ellen Schwartz. 2000. Cigarettes and Alcohol: Substitutes or Complements? NBER Working Paper 7535.

http://www.nber.org/papers/w7535

DeSimone, Jeff. 2001. The Effect of Cocaine Prices on Crime. Economic Inquiry 39(4): 627-43.

http://dx.doi.org/10.1093/ei/39.4.627

DiNardo, John E. 1993. Law Enforcement, the Price of Cocaine, and Cocaine Use. Mathematical and Computer Modelling 17(2): 53-64.

http://www.sciencedirect.com/science/article/pii/089571779390239U

Dobkin, Carlos and Nancy Nicosia. 2009. The War on Drugs: Methamphetamine, Public Health, and Crime. American Economic Review 99(1): 324-49.

http://www. aeaweb.org/articles.php?doi=10.1257/aer.99.1.324

Gallet, Craig A. 2007. The Demand for Alcohol: A Meta-Analysis of Elasticities. Australian Journal of Agricultural and Resource Economics 51(2): 121-35.

http://dx.doi.org/10.1111/j.1467-8489.2007.00365.x

Gallet, Craig A. and John A. List. 2003. Cigarette Demand: A Meta-Analysis of Elasticities. Health Economics 12(10): 821-35.

http://dx.doi.org/10.1002/hec.765

Horowitz, Joel L. 2001. Should the DEA's STRIDE Data Be Used for Economic Analyses of Markets for Illegal Drugs? Journal of the American Statistical Association 96(456): 1254-71.

http://amstat.tandfonline.com/doi/abs/10.1198/016214501753381904

Johnson, Rucker and Steven Raphael. 2012. How Much Crime Reduction Does the Marginal Prisoner Buy? Journal of Law and Economics 55(2): 275-310.

http://www.jstor.org/stable/10.1086/664073 
Jones, Christopher M., Karin A. Mack, and Leonard J. Paulozzi. 2013. Pharmaceutical Overdose Deaths, United States, 2010. Journal of the American Medical Association 309(7): 657-59.

http://dx.doi.org/10.1001/jama.2013.272

Kuziemko, Ilyana and Steven D Levitt. 2004. An Empirical Analysis of Imprisoning Drug Offenders. Journal of Public Economics 88(9-10): 2043-66.

http://www.sciencedirect.com/science/article/pii/s0047272703000203

Liu, Jin-Long, Jin-Tan Liu, James K. Hammitt, and Shin-Yi Chou. 1999. The Price Elasticity of Opium in Taiwan, 1914-1942. Journal of Health Economics 18(6): 795-810.

http://www.sciencedirect.com/science/article/pii/s0167629699000235

Miron, Jeffrey A. and Katherine Waldock. 2010. The Budgetary Impact of Ending Drug Prohibition. Washington, DC: Cato Institute.

http://www.cato.org/pubs/wtpapers/DrugProhibitionWP.pdf

Nicosia, Nancy, Rosalie Liccardo Pacula, Beau Kilmer, Russell Lundberg, and James Chiesa. 2009. The Economic Cost of Methamphetamine Use in the United States, 2005. Santa Monica, CA: Rand Corporation.

http://www.rand.org/pubs/monographs/MG829

Nonnemaker, James, Mark Engelen, and Daniel Shive. 2011. Are Methamphetamine Precursor Control Laws Effective Tools to Fight the Methamphetamine Epidemic? Health Economics 20(5): 519-531.

http://dx.doi.org/10.1002/hec.1610

Ohsfeldt, Robert L. and Raymond G. Boyle. 1999. Tobacco Taxes, Smoking Restrictions, and Tobacco Use. In Frank J. Chaloupka, Michael Grossman, Warren K. Bickel, and Henry Saffer, editors, The Economic Analysis of Substance Use and Abuse: An Integration of Econometrics and Behavioral Economic Research, pp. 15-30. University of Chicago Press.

http: //www. nber.org/chapters/c11154

Orzechowski and Walker. 2011. The Tax Burden on Tobacco: Historical Compilation, volume 46. Arlington, VA: Orzechowski and Walker.

http://nocigtax.com/upload/file/158/Tax_Burden_on_Tobacco_vol._46_FY2011.pdf

Ours, Jan C. van. 1995. The Price Elasticity of Hard Drugs: The Case of Opium in the Dutch East Indies, 1923-1938. Journal of Political Economy 103(2): 261-279.

http://www.jstor.org/stable/2138640

Rawson, Richard A., M. Douglas Anglin, and Walter Ling. 2001. Will the Methamphetamine Problem Go Away? Journal of Addictive Diseases 21(1): 5-19.

http://www.tandfonline.com/doi/abs/10.1300/J069v21n01_02

Rydell, C. Peter and Susan S. Everingham. 1994. Controlling Cocaine: Supply Versus Demand Programs. Santa Monica, CA: Rand Corporation.

http://www.rand.org/pubs/monograph_reports/MR33

Saffer, Henry and Frank J. Chaloupka. 1999. The Demand for Illicit Drugs. Economic Inquiry 37(3): 401-11.

http://dx.doi.org/10.1111/j.1465-7295.1999.tb01439.x 
Suo, Steve. 2004. Unnecessary Epidemic. Oregonian October 3-7.

http://www.oregonlive.com/special/oregonian/meth

Surveillance, Epidemiology, and End Results (SEER). 2011. US Population Data 1969-2009. National Cancer Institute, DCCPS, Surveillance Research Program, Surveillance Systems Branch.

http://seer.cancer.gov/popdata

[US DEA] United States Drug Enforcement Administration. 1995. Implementation of the Domestic Chemical Diversion Control Act of 1993 (PL 103-200). Federal Register 60(120): 32447-66.

https://federalregister.gov/a/94-25071

1997. Temporary Exemption From Chemical Registration for Distributors of Pseudoephedrine and Phenylpropanolamine Products. Federal Register 62(201): 53959-60.

https://federalregister.gov/a/97-27453

[US GAO] United States Government Accountability Office. 2013. State Approaches Taken to Control Access to Key Methamphetamine Ingredient Show Varied Impact on Domestic Drug Labs. GAO Report GAO-13-204.

http://www.gao.gov/assets/660/651709.pdf

Wagenaar, Alexander C., Matthew J. Salois, and Kelli A. Komro. 2009. Effects of Beverage Alcohol Price and Tax Levels on Drinking: A Meta-Analysis of 1003 Estimates From 112 Studies. Addiction 104(2): 179-90.

http://dx.doi.org/10.1111/j.1360-0443.2008.02438.x

Yuan, Yuehong and Jonathan P. Caulkins. 1998. The Effect of Variation in High-Level Domestic Drug Enforcement on Variation in Drug Prices. Socio-Economic Planning Sciences 32(4): 265-76.

http://www. ingentaconnect. com/content/els/00380121/1998/00000032/00000004/art00037

Zill, Nicholas. 2011. Adoption from Foster Care: Aiding Children While Saving Public Money. Brookings Institution Center on Children and Families Brief 43.

http://www.brookings.edu/ /media/research/files/reports/2011/5/adoption\%20foster\%

20care 20 zill/05_adoption_foster_care_zill.pdf 
Figure 1: Ratio of median monthly expected retail prices of meth, heroin, and cocaine relative to their respective values in January 1995, STRIDE, 1995-1999

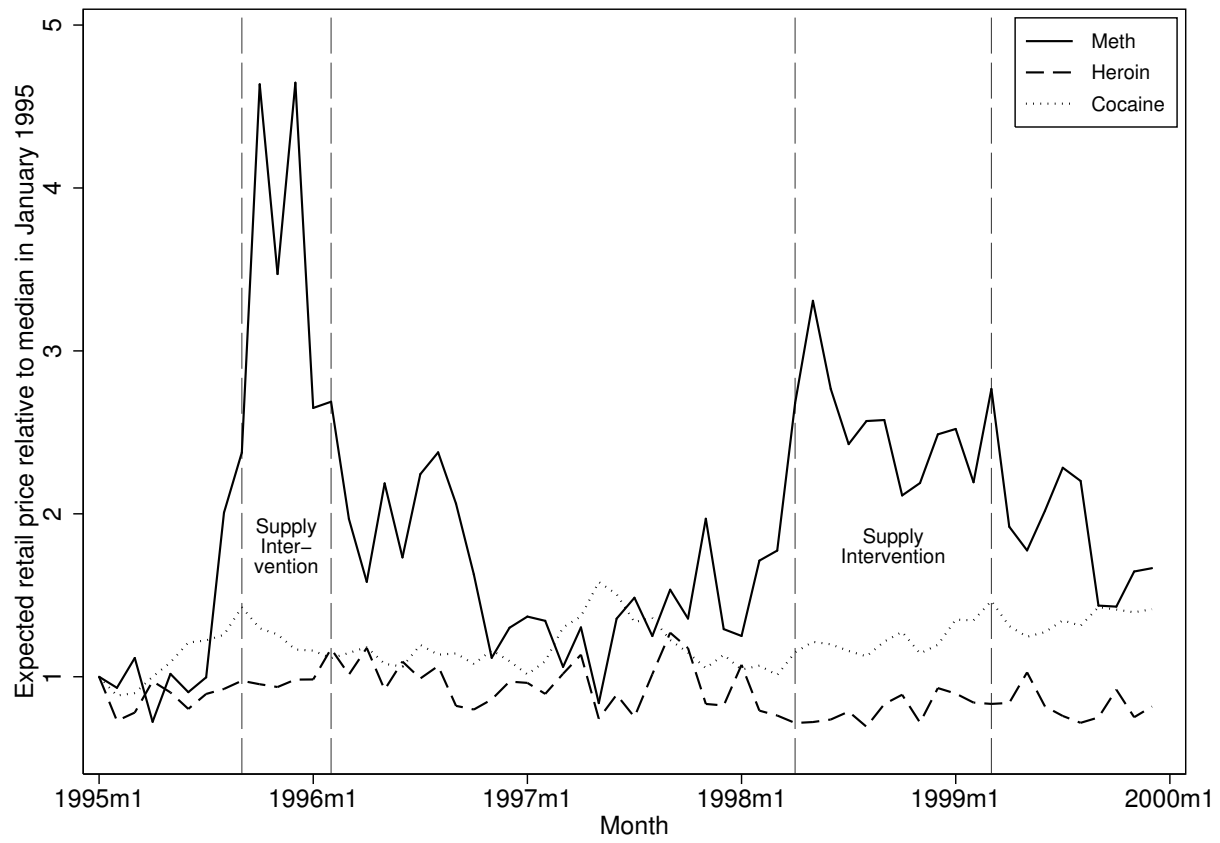

Notes: Authors' calculations from STRIDE. Expected price estimates come from random coefficient models of both purity and price, following the methodology of Arkes et al. (2004). Estimates from these models are available from the authors. Prices are inflated to 2002 dollars by the All Urban CPI series. 
Figure 2: Estimated own-price elasticities of demand for self-admitted methamphetamine treatment admissions with respect to the price of methamphetamine, 1995-1999

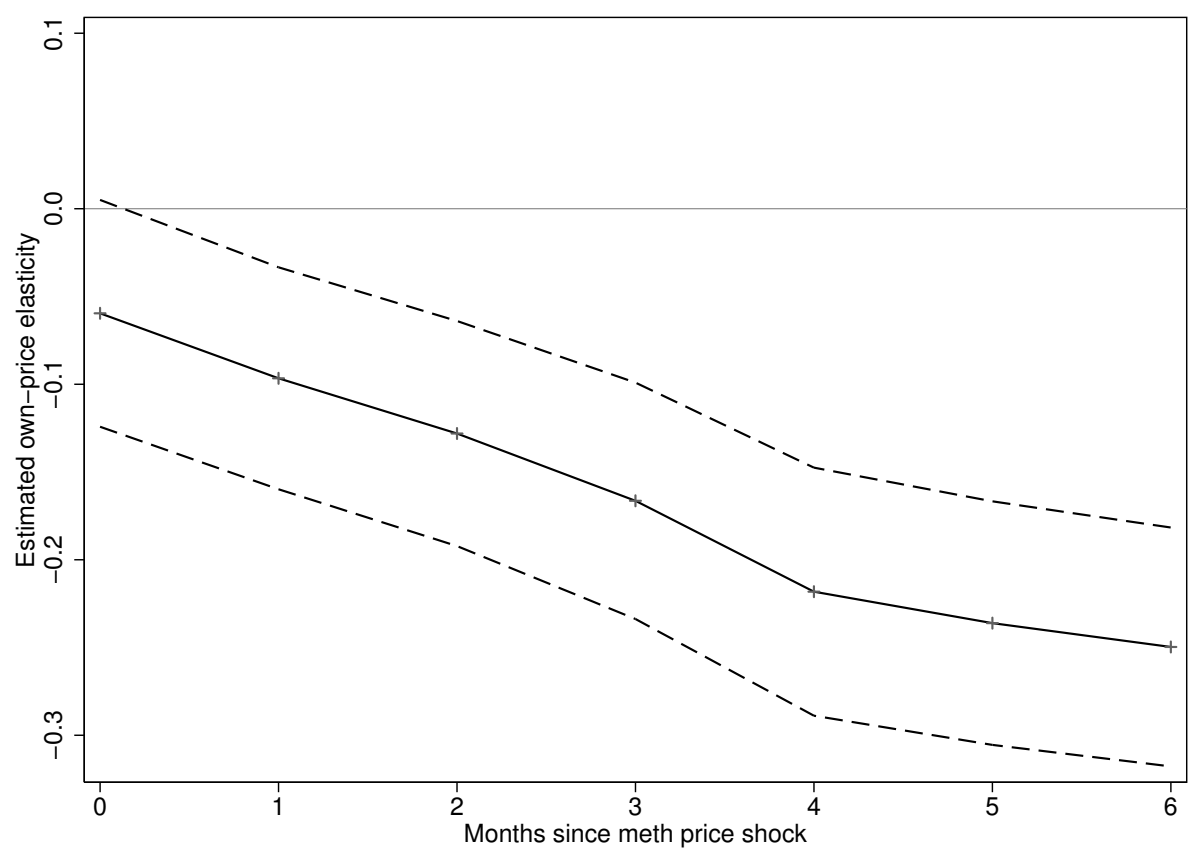

Notes: Each plot point represents a coefficient estimate from a single 2SLS regression model. Dashed lines show $90 \%$ confidence bounds derived from standard errors that account for heteroskedasticity. 
Figure 3: Estimated cross-price elasticities of demand for self-admitted treatment admissions with respect to the price of methamphetamine, by drug, 1995-1999
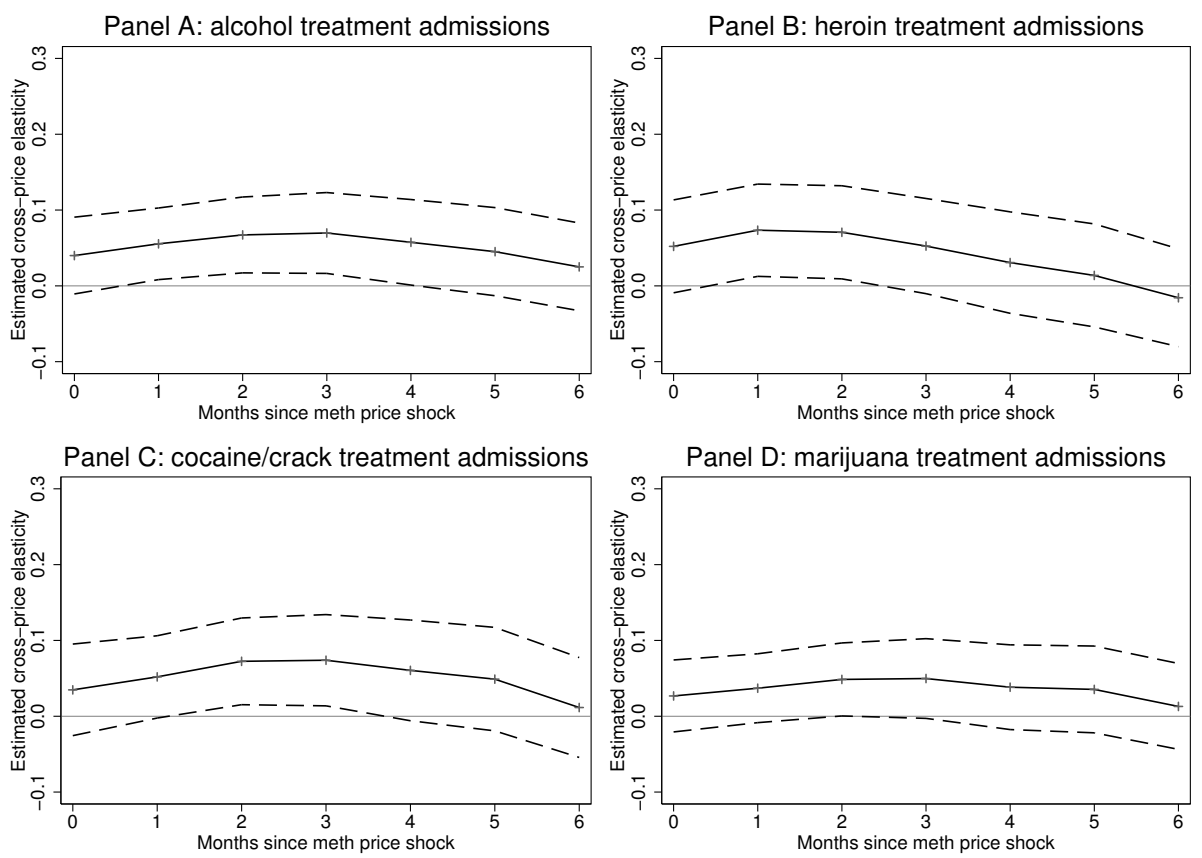

Notes: Each plot point represents a coefficient estimate from a single 2SLS regression model. Dashed lines show $90 \%$ confidence bounds derived from standard errors that account for heteroskedasticity. 
Table 1: Selected descriptive statistics, 1995-1999

\begin{tabular}{|c|c|c|c|c|c|c|}
\hline Variables & Source & $\mathrm{N}$ & Mean & Std. dev. & Min. & Max. \\
\hline \multicolumn{7}{|l|}{ Proxies for drug use } \\
\hline Meth admissions & TEDS & 2,640 & 232 & 599 & 0 & 4643 \\
\hline Meth admissions, self-referred & TEDS & 2,640 & 71 & 212 & 0 & 1848 \\
\hline Alcohol admissions & TEDS & 2,640 & 2082 & 2754 & 34 & 20522 \\
\hline Alcohol admissions, self-referred & TEDS & 2,640 & 613 & 918 & 0 & 6567 \\
\hline Cocaine/crack admissions & TEDS & 2,640 & 1012 & 1701 & 4 & 12158 \\
\hline Cocaine/crack admissions, self-referred & TEDS & 2,640 & 383 & 634 & 0 & 4125 \\
\hline Heroin admissions & TEDS & 2,640 & 520 & 1112 & 0 & 6520 \\
\hline Heroin admissions, self-referred & TEDS & 2,640 & 314 & 766 & 0 & 5464 \\
\hline Marijuana admissions & TEDS & 2,640 & 927 & 1162 & 19 & 8323 \\
\hline \multicolumn{7}{|l|}{ Expected retail prices (\$/pure g) } \\
\hline Meth price & STRIDE & 1,398 & 267 & 192 & 36 & 1483 \\
\hline Meth price, imputed & STRIDE & 2,640 & 228 & 95 & 86 & 551 \\
\hline Crack cocaine price & STRIDE & 1,605 & 91 & 32 & 43 & 276 \\
\hline Crack cocaine price, imputed & STRIDE & 2,640 & 103 & 24 & 59 & 192 \\
\hline Powder cocaine price & STRIDE & 1,520 & 106 & 40 & 47 & 345 \\
\hline Powder cocaine price, imputed & STRIDE & 2,640 & 102 & 23 & 57 & 198 \\
\hline Heroin price & STRIDE & 1,011 & 419 & 149 & 176 & 983 \\
\hline $\begin{array}{l}\text { Heroin price, imputed } \\
\text { Controls }\end{array}$ & STRIDE & 2,640 & 434 & 65 & 335 & 614 \\
\hline Population aged $15-49$ years $(1,000 s)$ & SEER & 2,640 & 2978 & 3249 & 309 & 17975 \\
\hline Unemployment rate (\%) & CPS & 2,640 & 4.57 & 1.23 & 1.70 & 9.00 \\
\hline Cigarette tax (\$/pack) & $\mathrm{O} \& W$ & 2,640 & 0.33 & 0.19 & 0.02 & 0.93 \\
\hline
\end{tabular}

Notes: Authors' calculations. The level of variation is state by month. Arizona, the District of Columbia, Indiana, Kentucky, Mississippi, West Virginia, and Wyoming are excluded from the sample because of poor data quality during some or all of the sample period. 
Table 2: Regressions of log self-admitted methamphetamine treatment admissions on drug prices, all states in sample, 1995-1999

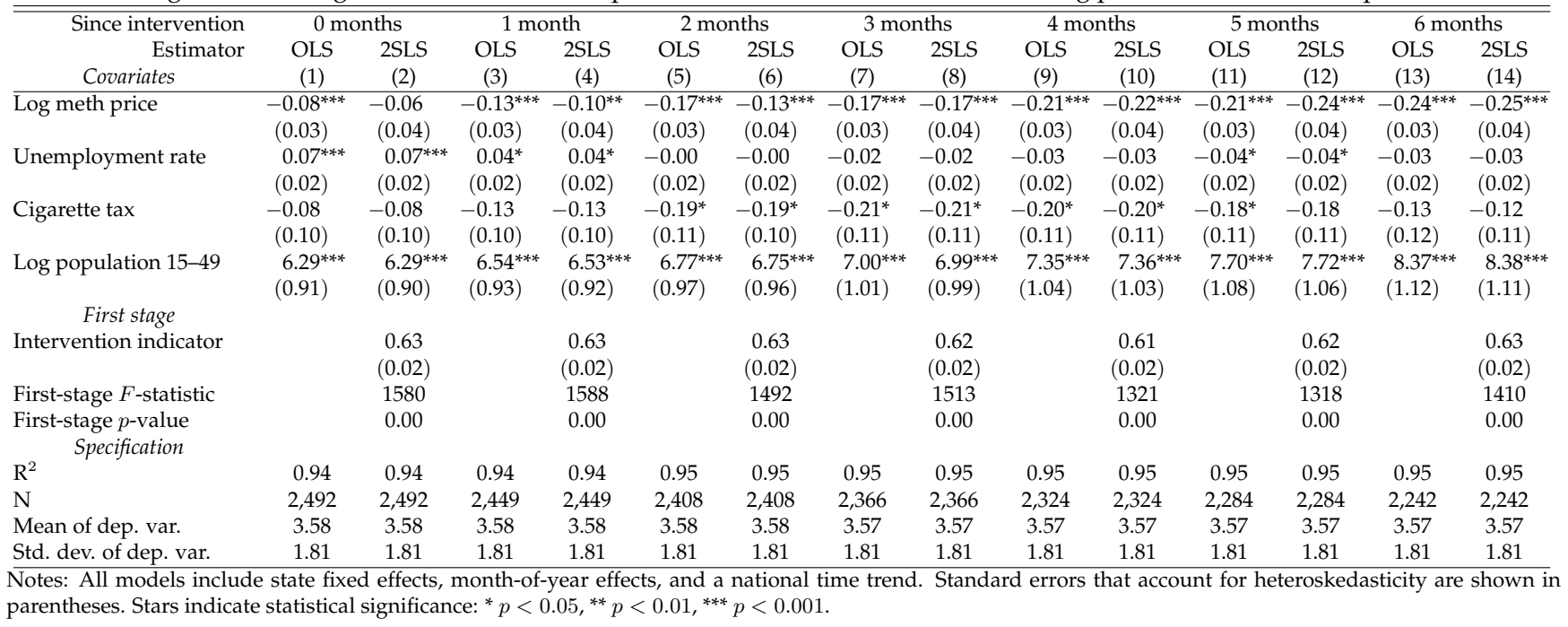


Table 3: Regressions of log self-admitted alcohol treatment admissions on drug prices, all states in sample, 1995-1999

\begin{tabular}{|c|c|c|c|c|c|c|c|c|c|c|c|c|c|c|}
\hline Since intervention & $0 \mathrm{~m}$ & aths & $1 \mathrm{mc}$ & nth & $2 \mathrm{~mol}$ & nths & $3 \mathrm{mo}$ & hths & $4 \mathrm{mo}$ & ths & $5 \mathrm{mo}$ & nths & $6 \mathrm{mo}$ & nths \\
\hline $\begin{array}{l}\text { Estimator } \\
\text { Covariates }\end{array}$ & $\begin{array}{l}\text { OLS } \\
(1)\end{array}$ & $\begin{array}{l}\text { 2SLS } \\
(2)\end{array}$ & $\begin{array}{l}\text { OLS } \\
(3)\end{array}$ & $\begin{array}{c}\text { 2SLS } \\
(4)\end{array}$ & $\begin{array}{l}\text { OLS } \\
(5)\end{array}$ & $\begin{array}{l}\text { 2SLS } \\
(6)\end{array}$ & $\begin{array}{c}\text { OLS } \\
(7)\end{array}$ & $\begin{array}{c}\text { 2SLS } \\
(8)\end{array}$ & $\begin{array}{l}\text { OLS } \\
(9)\end{array}$ & $\begin{array}{c}\text { 2SLS } \\
(10)\end{array}$ & $\begin{array}{l}\text { OLS } \\
(11)\end{array}$ & $\begin{array}{c}\text { 2SLS } \\
(12)\end{array}$ & $\begin{array}{l}\text { OLS } \\
(13)\end{array}$ & $\begin{array}{c}\text { 2SLS } \\
(14)\end{array}$ \\
\hline Log meth price & $\begin{array}{c}0.01 \\
(0.02)\end{array}$ & $\begin{array}{c}0.04 \\
(0.03)\end{array}$ & $\begin{array}{c}0.01 \\
(0.02)\end{array}$ & $\begin{array}{r}0.06^{*} \\
(0.03)\end{array}$ & $\begin{array}{c}0.01 \\
(0.02)\end{array}$ & $\begin{array}{l}0.07^{* *} \\
(0.03)\end{array}$ & $\begin{array}{c}0.03 \\
(0.02)\end{array}$ & $\begin{array}{l}0.07^{* *} \\
(0.03)\end{array}$ & $\begin{array}{c}0.01 \\
(0.03)\end{array}$ & $\begin{array}{r}0.06^{*} \\
(0.03)\end{array}$ & $\begin{array}{c}0.00 \\
(0.02)\end{array}$ & $\begin{array}{c}0.05 \\
(0.04)\end{array}$ & $\begin{array}{c}-0.01 \\
(0.03)\end{array}$ & $\begin{array}{c}0.03 \\
(0.04)\end{array}$ \\
\hline Unemployment rate & $\begin{array}{l}0.09 * * * \\
(0.02)\end{array}$ & $\begin{array}{l}0.09 * * * \\
(0.02)\end{array}$ & $\begin{array}{l}0.08^{* * *} \\
(0.02)\end{array}$ & $\begin{array}{l}0.08^{* * *} \\
(0.02)\end{array}$ & $\begin{array}{l}0.07^{* * *} \\
(0.02)\end{array}$ & $\begin{array}{l}0.07^{* * *} \\
(0.02)\end{array}$ & $\begin{array}{l}0.04^{* *} \\
(0.02)\end{array}$ & $\begin{array}{l}0.04^{* *} \\
(0.02)\end{array}$ & $\begin{array}{c}0.02 \\
(0.02)\end{array}$ & $\begin{array}{c}0.02 \\
(0.02)\end{array}$ & $\begin{array}{c}0.00 \\
(0.02)\end{array}$ & $\begin{array}{c}0.00 \\
(0.02)\end{array}$ & $\begin{array}{c}-0.01 \\
(0.02)\end{array}$ & $\begin{array}{c}-0.02 \\
(0.02)\end{array}$ \\
\hline Cigarette tax & $\begin{array}{l}0.19^{* *} \\
(0.09)\end{array}$ & $\begin{array}{l}0.19^{* *} \\
(0.09)\end{array}$ & $\begin{array}{l}0.19^{* *} \\
(0.08)\end{array}$ & $\begin{array}{l}0.19^{* *} \\
(0.08)\end{array}$ & $\begin{array}{l}0.18^{* *} \\
(0.08)\end{array}$ & $\begin{array}{l}0.18^{* *} \\
(0.08)\end{array}$ & $\begin{array}{r}0.14^{*} \\
(0.09)\end{array}$ & $\begin{array}{c}0.13 \\
(0.08)\end{array}$ & $\begin{array}{c}0.11 \\
(0.08)\end{array}$ & $\begin{array}{c}0.09 \\
(0.08)\end{array}$ & $\begin{array}{c}0.09 \\
(0.08)\end{array}$ & $\begin{array}{c}0.08 \\
(0.08)\end{array}$ & $\begin{array}{c}0.09 \\
(0.09)\end{array}$ & $\begin{array}{c}0.08 \\
(0.09)\end{array}$ \\
\hline Log population 15-49 & $\begin{array}{l}2.91^{* * *} \\
(0.75)\end{array}$ & $\begin{array}{l}2.91^{* * *} \\
(0.75)\end{array}$ & $\begin{array}{l}2.93^{* * *} \\
(0.78)\end{array}$ & $\begin{array}{l}2.92^{* * *} \\
(0.78)\end{array}$ & $\begin{array}{l}2.97^{* * *} \\
(0.82)\end{array}$ & $\begin{array}{l}2.95^{* * *} \\
(0.82)\end{array}$ & $\begin{array}{l}3.06^{* * *} \\
(0.85)\end{array}$ & $\begin{array}{l}3.04^{* * *} \\
(0.84)\end{array}$ & $\begin{array}{l}3.10^{* * *} \\
(0.87)\end{array}$ & $\begin{array}{l}3.07^{* * *} \\
(0.87)\end{array}$ & $\begin{array}{l}3.23^{* * *} \\
(0.89)\end{array}$ & $\begin{array}{l}3.21^{* * *} \\
(0.88)\end{array}$ & $\begin{array}{l}3.37^{* * *} \\
(0.91)\end{array}$ & $\begin{array}{l}3.35^{* * *} \\
(0.90)\end{array}$ \\
\hline $\begin{array}{c}\text { First stage } \\
\text { Intervention indicator }\end{array}$ & & $\begin{array}{c}0.63 \\
(0.02)\end{array}$ & & $\begin{array}{c}0.63 \\
(0.02)\end{array}$ & & $\begin{array}{c}0.63 \\
(0.02)\end{array}$ & & $\begin{array}{c}0.62 \\
(0.02)\end{array}$ & & $\begin{array}{c}0.61 \\
(0.02)\end{array}$ & & $\begin{array}{c}0.62 \\
(0.02)\end{array}$ & & $\begin{array}{c}0.64 \\
(0.02)\end{array}$ \\
\hline $\begin{array}{l}\text { First-stage } F \text {-statistic } \\
\text { First-stage } p \text {-value }\end{array}$ & & $\begin{array}{l}1647 \\
0.00\end{array}$ & & $\begin{array}{l}1643 \\
0.00\end{array}$ & & $\begin{array}{l}1542 \\
0.00\end{array}$ & & $\begin{array}{l}1548 \\
0.00\end{array}$ & & $\begin{array}{l}1346 \\
0.00\end{array}$ & & $\begin{array}{l}1344 \\
0.00\end{array}$ & & $\begin{array}{l}1441 \\
0.00\end{array}$ \\
\hline $\begin{array}{l}\mathrm{R}^{2} \\
\mathrm{~N}\end{array}$ & $\begin{array}{c}0.91 \\
2,605\end{array}$ & $\begin{array}{c}0.91 \\
2,605\end{array}$ & $\begin{array}{c}0.91 \\
2,561\end{array}$ & $\begin{array}{c}0.91 \\
2,561\end{array}$ & $\begin{array}{c}0.91 \\
2,517\end{array}$ & $\begin{array}{c}0.91 \\
2,517\end{array}$ & $\begin{array}{c}0.91 \\
2.473\end{array}$ & $\begin{array}{c}0.91 \\
2.473\end{array}$ & $\begin{array}{c}0.91 \\
2.429\end{array}$ & $\begin{array}{c}0.91 \\
2.429\end{array}$ & $\begin{array}{c}0.91 \\
2,385\end{array}$ & $\begin{array}{c}0.91 \\
2.385\end{array}$ & $\begin{array}{c}0.91 \\
2341\end{array}$ & $\begin{array}{c}0.91 \\
2,341\end{array}$ \\
\hline Mean of dep. var. & 6.56 & 6.56 & 6.56 & 6.56 & 6.56 & 6.56 & 6.55 & 6.55 & 6.55 & 6.55 & 6.55 & 6.55 & 6.55 & 6.55 \\
\hline Std. dev. of dep. var. & 1.09 & 1.09 & 1.09 & 1.09 & 1.09 & 1.09 & 1.09 & 1.09 & 1.09 & 1.09 & 1.09 & 1.09 & 1.09 & 1.09 \\
\hline
\end{tabular}


Table 4: Regressions of log self-admitted heroin treatment admissions on drug prices, all states in sample, 1995-1999

\begin{tabular}{|c|c|c|c|c|c|c|c|c|c|c|c|c|c|c|}
\hline \multirow{2}{*}{$\begin{array}{l}\text { Since intervention } \\
\text { Estimator } \\
\text { Covariates }\end{array}$} & \multicolumn{2}{|c|}{ 0 months } & \multicolumn{2}{|c|}{1 month } & \multicolumn{2}{|c|}{2 months } & \multicolumn{2}{|c|}{3 months } & \multicolumn{2}{|c|}{4 months } & \multicolumn{2}{|c|}{ 5 months } & \multicolumn{2}{|c|}{ (6 months } \\
\hline & $\begin{array}{l}\text { OLS } \\
(1)\end{array}$ & $\begin{array}{l}\text { 2SLS } \\
\text { (2) }\end{array}$ & $\begin{array}{l}\text { OLS } \\
\text { (3) }\end{array}$ & $\begin{array}{c}\text { 2SLS } \\
(4)\end{array}$ & $\begin{array}{l}\text { OLS } \\
(5)\end{array}$ & $\begin{array}{l}\text { 2SLS } \\
\text { (6) }\end{array}$ & $\begin{array}{c}\text { OLS } \\
\text { (7) }\end{array}$ & $\begin{array}{c}\text { 2SLS } \\
(8)\end{array}$ & $\begin{array}{c}\text { OLS } \\
\text { (9) }\end{array}$ & $\begin{array}{c}\text { 2SLS } \\
(10)\end{array}$ & $\begin{array}{l}\text { OLS } \\
(11)\end{array}$ & $\begin{array}{l}\text { 2SLS } \\
(12)\end{array}$ & $\begin{array}{l}\text { OLS } \\
(13)\end{array}$ & $\begin{array}{c}\text { 2SLS } \\
(14)\end{array}$ \\
\hline Log meth price & $\begin{array}{c}0.05 \\
(0.03)\end{array}$ & $\begin{array}{c}0.05 \\
(0.04)\end{array}$ & $\begin{array}{c}0.04 \\
(0.02)\end{array}$ & $\begin{array}{c}0.07^{* *} \\
(0.04)\end{array}$ & $\begin{array}{c}0.02 \\
(0.03)\end{array}$ & $\begin{array}{c}0.07^{*} \\
(0.04)\end{array}$ & $\begin{array}{c}0.02 \\
(0.03)\end{array}$ & $\begin{array}{c}0.05 \\
(0.04)\end{array}$ & $\begin{array}{c}-0.03 \\
(0.03)\end{array}$ & $\begin{array}{c}0.03 \\
(0.04)\end{array}$ & $\begin{array}{c}-0.03 \\
(0.03)\end{array}$ & $\begin{array}{c}0.01 \\
(0.04)\end{array}$ & $\begin{array}{r}-0.05^{*} \\
(0.03)\end{array}$ & $\begin{array}{c}-0.02 \\
(0.04)\end{array}$ \\
\hline Log heroin price & $\begin{array}{c}-0.08 \\
(0.08)\end{array}$ & $\begin{array}{c}-0.08 \\
(0.08)\end{array}$ & $\begin{array}{c}-0.03 \\
(0.08)\end{array}$ & $\begin{array}{c}-0.04 \\
(0.08)\end{array}$ & $\begin{array}{c}-0.19^{* *} \\
(0.08)\end{array}$ & $\begin{array}{c}-0.19^{* *} \\
(0.08)\end{array}$ & $\begin{array}{r}-0.15^{*} \\
(0.08)\end{array}$ & $\begin{array}{c}-0.16^{* *} \\
(0.08)\end{array}$ & $\begin{array}{r}-0.14^{*} \\
(0.08)\end{array}$ & $\begin{array}{r}-0.14^{*} \\
(0.08)\end{array}$ & $\begin{array}{r}-0.14^{*} \\
(0.08)\end{array}$ & $\begin{array}{r}-0.14^{*} \\
(0.08)\end{array}$ & $\begin{array}{c}-0.18^{* *} \\
(0.09)\end{array}$ & $\begin{array}{c}-0.18^{* *} \\
(0.09)\end{array}$ \\
\hline Unemployment rate & $\begin{array}{l}0.08^{* * *} \\
(0.02)\end{array}$ & $\begin{array}{l}0.08^{* * *} \\
(0.02)\end{array}$ & $\begin{array}{l}0.07^{* * *} \\
(0.02)\end{array}$ & $\begin{array}{l}0.07^{* * *} \\
(0.02)\end{array}$ & $\begin{array}{l}0.07^{* * *} \\
(0.02)\end{array}$ & $\begin{array}{l}0.07^{* * *} \\
(0.02)\end{array}$ & $\begin{array}{l}0.06^{* *} \\
(0.02)\end{array}$ & $\begin{array}{l}0.05^{* *} \\
(0.02)\end{array}$ & $\begin{array}{c}0.04 \\
(0.02)\end{array}$ & $\begin{array}{c}0.04 \\
(0.02)\end{array}$ & $\begin{array}{c}0.01 \\
(0.03)\end{array}$ & $\begin{array}{c}0.01 \\
(0.03)\end{array}$ & $\begin{array}{c}-0.01 \\
(0.03)\end{array}$ & $\begin{array}{r}-0.01 \\
(0.02)\end{array}$ \\
\hline Cigarette tax & $\begin{array}{c}0.04 \\
(0.11)\end{array}$ & $\begin{array}{c}0.04 \\
(0.11)\end{array}$ & $\begin{array}{c}0.07 \\
(0.10)\end{array}$ & $\begin{array}{c}0.06 \\
(0.10)\end{array}$ & $\begin{array}{c}0.07 \\
(0.10)\end{array}$ & $\begin{array}{c}0.07 \\
(0.10)\end{array}$ & $\begin{array}{c}0.06 \\
(0.10)\end{array}$ & $\begin{array}{c}0.05 \\
(0.10)\end{array}$ & $\begin{array}{c}0.04 \\
(0.10)\end{array}$ & $\begin{array}{c}0.03 \\
(0.10)\end{array}$ & $\begin{array}{c}0.03 \\
(0.11)\end{array}$ & $\begin{array}{c}0.01 \\
(0.10)\end{array}$ & $\begin{array}{c}0.04 \\
(0.11)\end{array}$ & $\begin{array}{c}0.03 \\
(0.11)\end{array}$ \\
\hline Log population $15-49$ & $\begin{array}{c}0.36 \\
(0.91)\end{array}$ & $\begin{array}{c}0.36 \\
(0.90)\end{array}$ & $\begin{array}{c}0.36 \\
(0.95)\end{array}$ & $\begin{array}{c}0.35 \\
(0.94)\end{array}$ & $\begin{array}{c}0.58 \\
(0.97)\end{array}$ & $\begin{array}{c}0.57 \\
(0.97)\end{array}$ & $\begin{array}{c}0.50 \\
(1.01)\end{array}$ & $\begin{array}{c}0.49 \\
(0.99)\end{array}$ & $\begin{array}{c}0.57 \\
(1.04)\end{array}$ & $\begin{array}{c}0.53 \\
(1.02)\end{array}$ & $\begin{array}{c}0.86 \\
(1.05)\end{array}$ & $\begin{array}{c}0.82 \\
(1.04)\end{array}$ & $\begin{array}{c}1.02 \\
(1.08)\end{array}$ & $\begin{array}{c}0.99 \\
(1.06)\end{array}$ \\
\hline $\begin{array}{c}\text { First stage } \\
\text { Intervention indicator }\end{array}$ & & $\begin{array}{c}0.65 \\
(0.02)\end{array}$ & & $\begin{array}{c}0.65 \\
(0.02)\end{array}$ & & $\begin{array}{c}0.65 \\
(0.02)\end{array}$ & & $\begin{array}{c}0.64 \\
(0.02)\end{array}$ & & $\begin{array}{c}0.64 \\
(0.02)\end{array}$ & & $\begin{array}{c}0.65 \\
(0.02)\end{array}$ & & $\begin{array}{c}0.67 \\
(0.02)\end{array}$ \\
\hline First-stage $F$-statistic & & 1623 & & 1622 & & 1522 & & 1521 & & 1287 & & 1270 & & 1361 \\
\hline $\begin{array}{c}\text { First-stage } p \text {-value } \\
\text { Specification }\end{array}$ & & 0.00 & & 0.00 & & 0.00 & & 0.00 & & 0.00 & & 0.00 & & 0.00 \\
\hline $\mathrm{R}^{2}$ & 0.96 & 0.96 & 0.96 & 0.96 & 0.96 & 0.96 & 0.96 & 0.96 & 0.96 & 0.96 & 0.96 & 0.96 & 0.96 & 0.96 \\
\hline $\mathrm{N}$ & 2,412 & 2,412 & 2,371 & 2,371 & 2,331 & 2,331 & 2,291 & 2,291 & 2,251 & 2,251 & 2,210 & 2,210 & 2,171 & 2,171 \\
\hline Mean of dep. var. & 5.22 & 5.22 & 5.22 & 5.22 & 5.22 & 5.22 & 5.22 & 5.22 & 5.22 & 5.22 & 5.22 & 5.22 & 5.22 & 5.22 \\
\hline Std. dev. of dep. var. & 2.10 & 2.10 & 2.10 & 2.10 & 2.10 & 2.10 & 2.10 & 2.10 & 2.10 & 2.10 & 2.10 & 2.10 & 2.10 & 2.10 \\
\hline
\end{tabular}


Table 5: Regressions of log self-admitted crack and powder cocaine treatment admissions on drug prices, all states in sample, 1995-1999

\begin{tabular}{|c|c|c|c|c|c|c|c|c|c|c|c|c|c|c|}
\hline \multirow{2}{*}{$\begin{array}{r}\text { Since intervention } \\
\text { Estimator }\end{array}$} & \multicolumn{2}{|c|}{0 months } & \multicolumn{2}{|c|}{1 month } & \multicolumn{2}{|c|}{2 months } & \multicolumn{2}{|c|}{3 months } & \multicolumn{2}{|c|}{4 months } & \multicolumn{2}{|c|}{5 months } & \multicolumn{2}{|c|}{6 months } \\
\hline & OLS & 2SLS & OLS & 2SLS & OLS & 2SLS & OLS & 2SLS & OLS & 2SLS & OLS & 2SLS & OLS & 2SLS \\
\hline Covariates & (1) & (2) & (3) & (4) & (5) & (6) & $(7)$ & (8) & (9) & $(10)$ & (11) & (12) & (13) & (14) \\
\hline \multirow[t]{2}{*}{ Log meth price } & -0.00 & 0.03 & 0.00 & 0.05 & 0.02 & $0.07^{* *}$ & $0.05^{*}$ & $0.07^{* *}$ & 0.04 & 0.06 & 0.03 & 0.05 & 0.02 & 0.01 \\
\hline & $(0.03)$ & $(0.04)$ & $(0.02)$ & $(0.03)$ & $(0.03)$ & $(0.03)$ & $(0.03)$ & $(0.04)$ & $(0.03)$ & $(0.04)$ & $(0.03)$ & $(0.04)$ & $(0.03)$ & $(0.04)$ \\
\hline \multirow[t]{2}{*}{ Log crack price } & $-0.09^{* *}$ & $-0.09^{* *}$ & $-0.08^{*}$ & $-0.08^{*}$ & -0.05 & -0.05 & $-0.09^{* *}$ & $-0.08^{* *}$ & -0.01 & -0.01 & -0.02 & -0.02 & -0.01 & -0.01 \\
\hline & $(0.04)$ & $(0.04)$ & $(0.05)$ & $(0.05)$ & $(0.04)$ & $(0.04)$ & $(0.04)$ & $(0.04)$ & $(0.05)$ & $(0.05)$ & $(0.06)$ & $(0.06)$ & $(0.05)$ & $(0.05)$ \\
\hline \multirow[t]{2}{*}{ Log powder price } & 0.01 & -0.00 & -0.00 & -0.02 & -0.05 & -0.06 & -0.05 & -0.06 & -0.05 & -0.06 & -0.06 & -0.06 & 0.02 & 0.02 \\
\hline & $(0.04)$ & $(0.04)$ & $(0.04)$ & $(0.04)$ & $(0.04)$ & $(0.04)$ & $(0.04)$ & $(0.04)$ & $(0.04)$ & $(0.04)$ & $(0.04)$ & $(0.05)$ & $(0.04)$ & $(0.04)$ \\
\hline \multirow[t]{2}{*}{ Unemployment rate } & $0.13^{* * *}$ & $0.13^{* * *}$ & $0.12^{* * *}$ & $0.12^{* * *}$ & $0.10^{* * *}$ & $0.10^{* * *}$ & $0.08^{* * *}$ & $0.08^{* * *}$ & $0.05^{* *}$ & $0.05^{* *}$ & 0.02 & 0.02 & -0.01 & -0.01 \\
\hline & $(0.02)$ & $(0.02)$ & $(0.02)$ & $(0.02)$ & $(0.02)$ & $(0.02)$ & $(0.02)$ & $(0.02)$ & $(0.02)$ & $(0.02)$ & $(0.02)$ & $(0.02)$ & $(0.02)$ & $(0.02)$ \\
\hline \multirow[t]{2}{*}{ Cigarette tax } & -0.00 & 0.00 & 0.02 & 0.01 & 0.02 & 0.01 & -0.02 & -0.02 & -0.05 & -0.05 & -0.08 & -0.09 & -0.10 & -0.10 \\
\hline & $(0.10)$ & $(0.10)$ & $(0.09)$ & $(0.09)$ & $(0.10)$ & $(0.09)$ & $(0.09)$ & $(0.09)$ & $(0.09)$ & $(0.09)$ & $(0.09)$ & $(0.09)$ & $(0.10)$ & $(0.10)$ \\
\hline \multirow[t]{2}{*}{ Log population 15-49 } & $3.07^{* * *}$ & $3.06^{* * *}$ & $3.11^{* * *}$ & $3.08^{* * *}$ & $3.16^{* * *}$ & $3.12^{* * *}$ & $3.23^{* * *}$ & $3.21^{* * *}$ & $3.31^{* * *}$ & $3.29^{* * *}$ & $3.48^{* * *}$ & $3.47^{* * *}$ & $3.70^{* * *}$ & $3.71^{* * *}$ \\
\hline & $(0.84)$ & $(0.84)$ & $(0.89)$ & $(0.88)$ & $(0.94)$ & $(0.94)$ & $(0.97)$ & $(0.96)$ & $(0.99)$ & $(0.98)$ & $(1.00)$ & $(0.99)$ & (1.03) & $(1.02)$ \\
\hline \multirow{3}{*}{$\begin{array}{c}\text { First stage } \\
\text { Intervention indicator }\end{array}$} & & & & & & & & & & & & & & \\
\hline & & 0.63 & & 0.63 & & 0.63 & & 0.62 & & 0.61 & & 0.61 & & 0.63 \\
\hline & & $(0.02)$ & & $(0.02)$ & & $(0.02)$ & & $(0.02)$ & & $(0.02)$ & & $(0.02)$ & & $(0.02)$ \\
\hline First-stage $F$-statistic & & 1461 & & 1453 & & 1362 & & 1337 & & 1145 & & 1141 & & 1209 \\
\hline First-stage $p$-value & & 0.00 & & 0.00 & & 0.00 & & 0.00 & & 0.00 & & 0.00 & & 0.00 \\
\hline Specification & & & & & & & & & & & & & & \\
\hline $\mathrm{R}^{2}$ & 0.92 & 0.92 & 0.92 & 0.92 & 0.92 & 0.92 & 0.92 & 0.92 & 0.92 & 0.92 & 0.92 & 0.92 & 0.92 & 0.92 \\
\hline $\mathrm{N}$ & 2,594 & 2,594 & 2,550 & 2,550 & 2,507 & 2,507 & 2,463 & 2,463 & 2,419 & 2,419 & 2,375 & 2,375 & 2,332 & 2,332 \\
\hline Mean of dep. var. & 6.07 & 6.07 & 6.07 & 6.07 & 6.07 & 6.07 & 6.06 & 6.06 & 6.06 & 6.06 & 6.06 & 6.06 & 6.05 & 6.05 \\
\hline Std. dev. of dep. var. & 1.33 & 1.33 & 1.33 & 1.33 & 1.33 & 1.33 & 1.33 & 1.33 & 1.33 & 1.33 & 1.33 & 1.33 & 1.33 & 1.33 \\
\hline
\end{tabular}


Table 6: Regressions of log self-admitted marijuana treatment admissions on drug prices, all states in sample, 1995-1999

\begin{tabular}{|c|c|c|c|c|c|c|c|c|c|c|c|c|c|c|}
\hline Since intervention & $0 \mathrm{~m}$ & aths & $1 \mathrm{mc}$ & nth & $2 \mathrm{mo}$ & aths & $3 \mathrm{mo}$ & iths & $4 \mathrm{mor}$ & nths & $5 \mathrm{~mol}$ & nths & $6 \mathrm{mo}$ & nths \\
\hline $\begin{array}{l}\text { Estimator } \\
\text { Covariates }\end{array}$ & $\begin{array}{l}\text { OLS } \\
(1)\end{array}$ & $\begin{array}{l}\text { 2SLS } \\
(2)\end{array}$ & $\begin{array}{l}\text { OLS } \\
(3)\end{array}$ & $\begin{array}{c}\text { 2SLS } \\
(4)\end{array}$ & $\begin{array}{l}\text { OLS } \\
(5)\end{array}$ & $\begin{array}{l}\text { 2SLS } \\
(6)\end{array}$ & $\begin{array}{l}\text { OLS } \\
(7)\end{array}$ & $\begin{array}{c}\text { 2SLS } \\
(8)\end{array}$ & $\begin{array}{l}\text { OLS } \\
(9)\end{array}$ & $\begin{array}{c}\text { 2SLS } \\
(10)\end{array}$ & $\begin{array}{l}\text { OLS } \\
(11)\end{array}$ & $\begin{array}{c}\text { 2SLS } \\
(12)\end{array}$ & $\begin{array}{l}\text { OLS } \\
(13)\end{array}$ & $\begin{array}{c}\text { 2SLS } \\
(14)\end{array}$ \\
\hline Log meth price & $\begin{array}{c}0.02 \\
(0.02)\end{array}$ & $\begin{array}{c}0.03 \\
(0.03)\end{array}$ & $\begin{array}{c}0.01 \\
(0.02)\end{array}$ & $\begin{array}{c}0.04 \\
(0.03)\end{array}$ & $\begin{array}{c}0.02 \\
(0.02)\end{array}$ & $\begin{array}{r}0.05^{*} \\
(0.03)\end{array}$ & $\begin{array}{c}0.03 \\
(0.02)\end{array}$ & $\begin{array}{c}0.05 \\
(0.03)\end{array}$ & $\begin{array}{c}0.02 \\
(0.03)\end{array}$ & $\begin{array}{c}0.04 \\
(0.03)\end{array}$ & $\begin{array}{c}0.01 \\
(0.02)\end{array}$ & $\begin{array}{c}0.04 \\
(0.03)\end{array}$ & $\begin{array}{c}0.00 \\
(0.03)\end{array}$ & $\begin{array}{c}0.01 \\
(0.03)\end{array}$ \\
\hline Unemployment rate & $\begin{array}{l}0.08^{* * *} \\
(0.02)\end{array}$ & $\begin{array}{l}0.08^{* * *} \\
(0.02)\end{array}$ & $\begin{array}{l}0.07^{* * *} \\
(0.02)\end{array}$ & $\begin{array}{l}0.07^{* * *} \\
(0.02)\end{array}$ & $\begin{array}{l}0.05^{* *} \\
(0.02)\end{array}$ & $\begin{array}{l}0.05^{* *} \\
(0.02)\end{array}$ & $\begin{array}{c}0.02 \\
(0.02)\end{array}$ & $\begin{array}{c}0.02 \\
(0.02)\end{array}$ & $\begin{array}{c}-0.00 \\
(0.02)\end{array}$ & $\begin{array}{c}-0.00 \\
(0.02)\end{array}$ & $\begin{array}{r}-0.02 \\
(0.02)\end{array}$ & $\begin{array}{r}-0.02 \\
(0.02)\end{array}$ & $\begin{array}{l}-0.04^{* *} \\
(0.02)\end{array}$ & $\begin{array}{l}-0.04^{* *} \\
(0.02)\end{array}$ \\
\hline Cigarette tax & $\begin{array}{l}0.27^{* * *} \\
(0.09)\end{array}$ & $\begin{array}{l}0.27^{* * *} \\
(0.09)\end{array}$ & $\begin{array}{l}0.27^{* * *} \\
(0.08)\end{array}$ & $\begin{array}{l}0.27^{* * *} \\
(0.08)\end{array}$ & $\begin{array}{l}0.25^{* * *} \\
(0.08)\end{array}$ & $\begin{array}{l}0.24^{* * *} \\
(0.08)\end{array}$ & $\begin{array}{l}0.19^{* *} \\
(0.08)\end{array}$ & $\begin{array}{l}0.19^{* *} \\
(0.08)\end{array}$ & $\begin{array}{r}0.14^{*} \\
(0.08)\end{array}$ & $\begin{array}{r}0.13^{*} \\
(0.08)\end{array}$ & $\begin{array}{c}0.10 \\
(0.08)\end{array}$ & $\begin{array}{c}0.10 \\
(0.08)\end{array}$ & $\begin{array}{c}0.08 \\
(0.09)\end{array}$ & $\begin{array}{c}0.08 \\
(0.08)\end{array}$ \\
\hline Log population 15-49 & $\begin{array}{l}2.14^{* * *} \\
(0.68)\end{array}$ & $\begin{array}{l}2.14^{* * *} \\
(0.67)\end{array}$ & $\begin{array}{l}2.22^{* * *} \\
(0.71)\end{array}$ & $\begin{array}{l}2.21^{* * *} \\
(0.71)\end{array}$ & $\begin{array}{l}2.30^{* * *} \\
(0.75)\end{array}$ & $\begin{array}{l}2.29^{* * *} \\
(0.75)\end{array}$ & $\begin{array}{l}2.43^{* * *} \\
(0.78)\end{array}$ & $\begin{array}{l}2.42^{* * *} \\
(0.77)\end{array}$ & $\begin{array}{l}2.53^{* * *} \\
(0.81)\end{array}$ & $\begin{array}{l}2.52^{* * *} \\
(0.80)\end{array}$ & $\begin{array}{l}2.67^{* * * *} \\
(0.83)\end{array}$ & $\begin{array}{l}2.65^{* * *} \\
(0.82)\end{array}$ & $\begin{array}{l}2.75^{* * * *} \\
(0.86)\end{array}$ & $\begin{array}{l}2.75^{* * *} \\
(0.86)\end{array}$ \\
\hline $\begin{array}{c}\text { First stage } \\
\text { Intervention indicator }\end{array}$ & & $\begin{array}{c}0.63 \\
(0.02)\end{array}$ & & $\begin{array}{c}0.63 \\
(0.02)\end{array}$ & & $\begin{array}{c}0.63 \\
(0.02)\end{array}$ & & $\begin{array}{c}0.62 \\
(0.02)\end{array}$ & & $\begin{array}{c}0.61 \\
(0.02)\end{array}$ & & $\begin{array}{c}0.62 \\
(0.02)\end{array}$ & & $\begin{array}{c}0.64 \\
(0.02)\end{array}$ \\
\hline $\begin{array}{l}\text { First-stage } F \text {-statistic } \\
\text { First-stage } p \text {-value }\end{array}$ & & $\begin{array}{l}1647 \\
0.00\end{array}$ & & $\begin{array}{l}1643 \\
0.00\end{array}$ & & $\begin{array}{l}1542 \\
0.00\end{array}$ & & $\begin{array}{l}1548 \\
0.00\end{array}$ & & $\begin{array}{l}1344 \\
0.00\end{array}$ & & $\begin{array}{l}1343 \\
0.00\end{array}$ & & $\begin{array}{l}1437 \\
0.00\end{array}$ \\
\hline $\begin{array}{l}\mathrm{R}^{2} \\
\mathrm{~N}\end{array}$ & $\begin{array}{c}0.89 \\
2,603\end{array}$ & $\begin{array}{c}0.89 \\
2,603\end{array}$ & $\begin{array}{c}0.89 \\
2,559\end{array}$ & $\begin{array}{c}0.89 \\
2,559\end{array}$ & $\begin{array}{c}0.89 \\
2,515\end{array}$ & $\begin{array}{c}0.89 \\
2,515\end{array}$ & $\begin{array}{c}0.89 \\
2.471\end{array}$ & $\begin{array}{c}0.89 \\
2471\end{array}$ & $\begin{array}{c}0.89 \\
2.427\end{array}$ & $\begin{array}{c}0.89 \\
2.427\end{array}$ & $\begin{array}{c}0.89 \\
2.383\end{array}$ & $\begin{array}{c}0.89 \\
2.383\end{array}$ & $\begin{array}{c}0.89 \\
2.339\end{array}$ & $\begin{array}{c}0.89 \\
2.339\end{array}$ \\
\hline Mean of dep. var. & 5.62 & 5.62 & 5.62 & 5.62 & 5.62 & 5.62 & 5.61 & 5.61 & 5.61 & 5.61 & 5.61 & 5.61 & 5.61 & 5.61 \\
\hline Std. dev. of dep. var. & 1.01 & 1.01 & 1.01 & 1.01 & 1.01 & 1.01 & 1.01 & 1.01 & 1.01 & 1.01 & 1.01 & 1.01 & 1.01 & 1.01 \\
\hline
\end{tabular}

